\title{
Entrepreneurship and University Spin-offs for (Academic) Employment?
}

\section{Stefano Boffo ${ }^{1}$, Augusto Cocorullo ${ }^{2}$, Francesco Gagliardi ${ }^{1}$}

${ }^{1}$ Institute for Research on Population and Social Policies, National Research Council, Rome, ${ }^{2}$ Department of Social Sciences, University of Naples Federico II, Naples.

\begin{abstract}
In the new Millennium Italian universities have lived many changes deeply reshaping academic institutions. A relevant aspect was the more and more significant need to answer the demand of society and respond the social pressure to accountability through the transfer of knowledge, innovation and technology to economy. It led to an extension of the so-called university Fourth Mission, an instrument dedicated to create spin-offs to share scientific research results with society. The paper investigates the present reality of university spin-offs in Italy by considering their growing number also in the light of their role of an instrument for academic job substitution. In particular, a tool to respond to the current condition of young Italian academic researchers increasingly affected by job offer reduction due to budget constraints, consequent university policies and new management issues.
\end{abstract}

Keywords: Entrepreneurship; University Spin-offs; Academic jobs. 


\section{Introduction}

Over the last few years universities have increasingly become aware of new demands from the economy (use of knowledge products) and society as a whole (extension of education level, needs for social mobility). This is an important root of the spin-offs' developing process, which is also related to the extended competition of academic institutions in a globalized world, confirmed by the exponential spread of MOOC (Massive Open Online Courses) and intensified diffusion of lifelong and recurrent university training. New aspects creating the conditions for a move from mass university to universal access to higher education (Trow 1973; 1999; 2006). The spread of these demands in the academic sphere meant a pulse for universities to better open to society in order to catch the needs of different social groups of users and to develop stronger ties with society as a whole. This active role implied a deep transformation of the identity of universities as institutions able at the same time to dialogue with society and to avoid to be overwhelmed by the contractual power of their interlocutors. A need also related to the present epistemologic feature of knowledge and to the changing modes of its production. Knowledge is a combination of explicit and tacit aspects were the transfer of results cannot leave aside users nor producers (Polanyi, 1966). As it is well known, knowledge production passed from the traditional "linear process" (basic research - applied research and innovation innovation - engineering) to an 'iterative and interactive' mode where there is a continuous mix between producers and users (from Mode 1 to Mode 2, as defined by Gibbons et al. 1994; see also Etzkowitz and Leydesdorff 1997; Nowotny et al. 2001). In some cases these transformations found universities inadequate or insufficiently prepared. Insufficiencies and shortcomings in the physical and pedagogical curricular as well as in the organizational and government structures have highlighted the increasing inadequacy of the quality of training and research products and overall of their organization in order to satisfy societal demands. This, in turn, has made urgent the problem of closer ties with the economic world seen as a potential source of resources and of orientating demand. At the same time, despite difficulties and inadequacies, higher education institutions remain key players, though no longer monopolistic, in the production, transfer and dissemination of knowledge and maintain a meaningful role for the social process of knowledge production. Academic institutions can act in knowledge creation and dissemination through a variety of mechanisms including contract work and collaborative research (Gunasekara 2006). This is the framework in which we see an increasing expansion of the set of activities that we call Third Mission, implying that they do not cover neither education nor research traditionally developed in the academic sphere. Here we refer to the generation, transmission, application, and safeguard of knowledge for the direct benefit of actors and groups outside the core academic bodies. These activities include different forms of knowledge transfer and encompass also the provision of lifelong learning and initiatives of social or civic 
engagement of the university. Being presently considered fundamental co-actors in the knowledge transfer process, to the productive sector and service (McQueen and Wallmark 1982; Chiesa and Piccaluga 2000; Benneworth and Charles 2004; D’Este, Mahdi and Neely 2009), academic institutions do not cover anymore this role only by granting patents to outsiders, but are more dedicated to promotion, creation and support of new enterprises for the economic and social exploitation of scientific research results, an aspect considered the Fourth Mission of universities (Geiger 2006; Kretz e Sá 2013). Academic institutions have also the opportunity to turn into instruments of growth closely linked with innovationdriven regional development processes. Although not recent (it has been already reported by "classical" fellows, e.g. Clark 1998; Etzkowitz and Leydesdroff 2000; Clarysse and Moray 2004) only in the last years the phenomenon of university spin-offs has become a "popular" target of interest among higher education researchers. Moreover, in Europe the attention to this growing form of exploitation of scientific research results has been focused not only at regional policy level - spin-offs are a major mechanism in the relationships between universities and business, as well in the creation of jobs and wealth - but also at the level of the re-organization of academic structures, which aim at a maximum impact of the results of university research (European Trend Chart on Innovation 2002; Degroof and Roberts 2004; Laredo 2007; Algieri et al. 2011). Based on a field research carried out in the years 2016 - 2018, including more than forty qualitative interviews in five academic institutions, the present paper focuses on the spin-offs as substitute opportunity of research jobs for young researchers who cannot anymore be absorbed by the Academia.

\section{University Spin-offs in Italy}

University spin-offs are presently one of the typical themes involved in the debate on the country's ability to value the innovative capabilities of own economic system. In the Italian case, the media and the specialized publications seem to offer a partial, uninformed and sometimes distorted image of the phenomenon (Piccarozzi et al. 2013; Rahim et al. 2014). Moreover, they almost never link spin-offs with the transformations of the university system and the academic institutions. For this reason, it seemed necessary to undertake a deepening of an issue lacking of qualitative information on the relationship university spinoffs/academic institutions, although statistically studied in some important reports (Netval 2005-2018; Anvur 2013; 2014; 2016; 2017). These insights allowed us to try to come out of a purely statistical dimension and to investigate specific subjects, stories and dynamics.

The research started from a preliminary phase of synthesis, filing and disciplining of the numerous and disparate definitions of academic spin-offs, which are progressively elaborated by researchers in the various studies on this subject. The analysis of literature reveals a substantial absence of a unique notion of the subject, a phenomenon that ends with the use of the same term to describe phenomena which are quite different in terms of 
nature and peculiarity. Such plurality of definitions «involves not only problems of a theoretical nature, but, above all, a practical one, as it makes very difficult to quantify the phenomenon and to compare it in terms of time and space dimensions, so that there are often significant deficiencies of the support policies that should be set in the programming phase and in the implementation phase» (Grossi and Ruggiero 2008, 58). Others (Steffensen, Rogers and Speakman 2000, 97) provided a definition we adopted in this paper because of its breadth: «A spin-off is a new company that is formed by individuals who were former employees of a parent organization, and a core technology that is transferred from the parent organization».

In Italy, the university spin-offs creation process started in the beginning of the 2000s and nearly 1.327 enterprises have been founded since (Netval 2018). In particular, the gradual increase in university spin-offs lasted until 2007, following a regular growth trend, with the creation of about 100 new entrepreneurial realities each year.

An important feature to be considered is the composition of university spin-offs research groups, an aspect which influences the future spin-offs life on the market. It is important that the group of researchers forming part of an academic spin-off be well calibrated in terms of research and technical-managerial skills. An analysis of the positions covered by founders of university spin-offs so far, shows that 52\% of them are research fellows, $32 \%$ full professors and $16 \%$ associate professors (Netval 2016). The weight of the young researchers is quite evidently overwhelming. It would certainly be even higher if it could be possible to consider the data concerning other young researchers in the staff, an information missing for the whole Italian universities but present in some academic institutions. The prevalence of research fellows among the spin-offs founders group is interesting if projected to a broader analysis of the present condition of research staff in Italian universities. In 2010 a new law for university ${ }^{1}$ has, among other effects, radically changed the research fellows recruitment. The law, abolishing the tenured research fellow (RTI), multiplied the apprenticeship ${ }^{2}$ roles, drastically reducing the tenure possibilities for these positions. In fact, the data referred to 2011-2018 show a sharp decline in the number of tenured research fellows, who passed from 23.740 in 2013 to 12.200 in 2019. The "Type B" researchers (tenure track) are 2.422 in 2018 and the residual number of old tenured

${ }^{1}$ Law 30 December 2010, n. 240 - "Rules on the organization of universities, academic staff and recruitment, authorizing the government to enhance the quality and efficiency of the university system", promoted by the Minister Gelmini, and published in the Official Gazette no. 10 of 14 January 2011 - Suppl. Ordinary n. 11.

${ }^{2}$ These figures are: the Research Grant, which can be recruited for a maximum of 4 years (subsequently increased to 6); the "Type A" fixed-term researcher (RTDa) (3 years and renewable for 2); the "Type B" time-limited researcher (RTDb) (3 years non-renewable). 
researchers (RTI) is 9778, when the "Type A" fixed-term ( non-tenured) researchers is growing since 2011 (3.701 units in 2018). It is interesting to emphasize the gradual deterioration of academic job perspectives for young researchers, an aspect which we relate to the increase in university spin-offs as substitute opportunity to academic jobs. Despite the main nature of university spin-offs is predominantly to enhance and apply the results of academic research, it seems reasonable to assume that, over time, the phenomenon has taken on an additional configuration (Simmons 2017; Cocorullo 2017). The increasing difficulties in finding a permanent position in universities encourages researcher fellows to intercept possible alternatives to academic career, both in terms of accumulation of economic resources and in terms of finding a physical environments where is possible to pursue their research interests and relative activities.

In this perspective, the university spin-offs act as an "anchor" for those that would otherwise be excluded from the research world for the present restrictions in academic recruitment. This is fully in line with what previously said about the research groups composition: there is a predominant percentage of researchers compared to professors, whether associate or full. However, it is wrong to suppose that in these class of researchers what is defined "entrepreneurial commitment" (Parente and Feola 2003) necessarily collide with the traditional "academic commitment". The results of our field research on spin-offs of 5 Italian Universities (Politecnico di Torino, Università di Trento, Scuola Supariore Sant'Anna di Pisa, Università degli Studi di Napoli Federico II and Università degli Studi di Messina) show that spin-off's young researchers maintain a high level of aspiration to academic jobs. It would be interesting to check in the future whether ( and in how many cases) the professional trajectory of young researchers-entrepreneurs will also evolve towards a formal academic position. If so, due to the dual purpose, the entrepreneurship inclination encouraged by the opportunity (what Acs and Varga 2005 and Acs 2006 call opportunity entrepreneurship) would come to establish an osmotic relationship of mutual compensation with entrepreneurship dictated by necessity (necessity entrepreneurship). In fact, investigate this aspect would require a specific research activity over the years that the present study does not allow and that it could be a future development.

\section{Conclusions}

The quantitative analysis of the university spin-offs allowed the reconstruction of the configuration assumed by the phenomenon in the Italian case. Because of the high concentration in central and northern areas of Italy, the image that emerged is of a rather fragmented and inhomogeneous reality. More generally, the spin-offs diffusion is higher in those areas with higher economic activity and closers to incubators and/or business accelerators, whose broader presence is in the Center-North of Italy. More generally, it is interesting to underline how the inconsistency (which sometimes is simply a lack) of 
national and local policies on scientific research has determined a quite inhomogeneous distribution of spin-offs at national level.

Another aspect which emerged is a likely correlation between the numerical decline of tenured academic positions and the growth of university spin-offs in Italy. As already stated, it is possible to put forward the hypothesis that spin-offs might play a role of academy-substitution for those who are unable to find a tenured academic position as a consequence of the job restriction introduced in the Italian legislation for universities. It is possible that this aspect might affect the researchers' enterprenurial attitude (in so far as they might perceive entrepreneurial activity as too risky and uncertain) and finally damage the market affirmation of the project they follow. A factor reinforced both by the lack of availability of venture capital and the real difficulty in identifying financial partners to join the project (Gupte 2007; Hayter 2016; Guerrero et al . 2016).

It's a pity that there still are present all these difficulties in university spin-offs. In fact, given the Italian industry structure - featuring from the large prevalence of small and medium-sized enterprises operating in sectors not always with a high technological impact - the university spin-offs would be among the most suitable subjects to start a revitalization and innovation process in a country traditionally reluctant both to invest in development and innovation and to interact with the research world.

\section{References}

Acs, Z.J., Varga, A. (2005). «Entrepreneurship, Agglomeration and Technological Change», Small Business Economics, vol. 24 n. 3, pp. 323-334.

Acs, Z.J. (2006). «How is Entrepreneurship Good for Economic Growth?», innovations Technology, Governance \& Globalization, vol. 1 n. 1, pp. 97-107.

Algieri, B., Aquino, A., Succurro, M. (2011). «Technology transfer offices and academic spin-off creation: the case of Italy», Journal of Technology Transfer, vol. 38 n. 4, pp. 382-400.

Benneworth, P., Charles, D. (2004). «University spin-off companies and territorial knowledge pool: building regional innovation competencies», paper presented at the DRUID Summer Conference 2004, Industrial Dynamics, Innovation and Development, Elsinore, Denmark, 14-16 June.

Chiesa, V., Piccaluga, A. (2000). «Exploitation and diffusion of public research: the case of academic spin-off companies in Italy», $R \& D$ Management, vol. 30 n. 4, pp. 329-339.

Clark, B.R. (1998). Creating Entrepreneurial Universities: Organizational Pathways of Transformation, Oxford: Iau Press/Pergamon/Elsevier Science Ltd.

Clarysse, B., Moray, N. (2004). «A process study of entrepreneurial team formation: the case of a research-based spin-off», Journal of Business Venturing, vol. 19 n. 1, pp. 5579. 
Cocorullo, A. (2017). «University Fourth Mission. Spin-offs and Academic Entrepreneurship: a theoretical review through the variety of definitions», in Eurashe (Aa.Vv.), 27th Annual Conference: Final Report.

D'este, P., Mahdi, S., Neely, A. (2009). «Academic Entrepreneurship: What are The Factors Shaping The Capacity of Academic Researchers to Identify and Exploit Entrepreneurial Opportunities?», paper presented at the DRUID Summer Conference 2009, CBS - Copenhagen Business School, Frederiksberg, Denmark, 17-19 June.

Degroof, J.J., Roberts, E.B. (2004). «Overcoming Weak Entrepreneurial Infrastructures for Academic Spin-Off Ventures», The Journal of Technology Transfer, vol. 29, n. 3, pp. 327-352.

Etzkowitz, H., Leydesdorff, L. (eds.) (1997). University and the Global Knowledge Economy, London: Pinter.

Etzkowitz, H., Leydesdorff, L. (2000). «The Dynamics of Innovation: From National Systems and Mode 2 to the Triple Helix of University - Industry - Government Relations», Research Policy, vol. 29, pp. 109-123.

European Trend Chart On Innovation (2002). «The changing role of public support to academic spin-offs», Policy Benchmarking Workshop, 19-20 February, European Commission, Enterprise Directorate-General Innovation/SME Programme.

Geiger, R.L. (2006), «The Quest For 'Economic Relevance' by US Research Universities», Higher Education Policy, vol. 19 n. 4, pp. 411-431.

Gibbons, M., Limoges, C., Nowotny, H., Schwartzman, S., Scott, P., Trow, M. (1994). The new production of knowledge. The dynamics of science and research in contemporary societies, London: Sage Publications.

Guerrero, M., Urbano, D., Fayolle, A., Klofsten, M., Milan, S. (2016). «Entrepreneurial universities: emerging models in the new social and economic landscape», Small Business Economics, vol. 47 n. 3, pp. 551-563.

Gunasekara C. (2006). «Leading the horses to the water: The dilemmas of academics and university managers in regional engagement», Journal of Sociology, vol. 42 n. 2, pp. 145-163.

Gupte, M.A. (2007). Success of University Spin-Offs. Network Activities and Moderating Effects of Internal Communication and Adhocracy, Wiesbaden, Germania: Deutscher Universitäts-Verlag.

Hayter, C.S. (2015). «Social Networks and the Success of University Spin-offs: Toward an Agenda for Regional Growth», Economic Development Quarterly, vol. 29 n. 1, pp. 313.

Kretz, A., Sá, C. (2013). «Third Stream, Fourth Mission: Perspectives on University Engagement with Economic Relevance», Higher Education Policy, vol. 26 n. 4, pp. 497-506.

Laredo, P. (2007). «Revisiting the third mission of universities: Toward a renewed categorization of university activities?», Higher Education Policy, vol. 20 n. 4, pp. 441456.

McQueen, D.H., Wallmark, J.T. (1982). «Spin-off Companies from Chalmers University of Technology», Technovation, vol. 1 n. 4, pp. 305-315. 
Nowotny, H., Scott, P., Gibbons, M. (2001). Re-thinking Science, Cambridge: Polity.

Parente, R., Feola, R. (2013). «Entrepreneurial intent and entrepreneurial commitment of young researchers», International Journal of Technology Management \& Sustainable Development, vol. 12 n. 2, pp. 155-166.

Piccarozzi, M., Silvestri, C., Stefanoni, A. (2013), «Un modello per la creazione di spin-off accademici: il caso dell'Università degli Studi della Tuscia», Impresa Progetto Electronic Journal of Management, n. 2 - 2013, pp. 1-29.

Polanyi, M. (1966). The Tacit Dimension, London: Routledge \& Kegan Paul.

Rahim, N.A., Mohamed, Z.B., Amrin, A. (2014), «Commercialization of Emerging Technology: The Role of Academic Entrepreneur», Procedia - Social and Behavioral Sciences, n. 169, pp. 53-60.

Ramaciotti, L., Daniele, C. (2016). Ricerca, valorizzazione dei risultati ed impatto - XIII Rapporto Netval sulla Valorizzazione della Ricerca nelle Università e negli Enti Pubblici di Ricerca in Italia, Pavia: Edizioni ETS.

Ramaciotti, L., Daniele, C. (2018). La rete del trasferimento tecnologico si rafforza con la clinical innovation - XIV Rapporto Netval sulla Valorizzazione della Ricerca nelle Università e negli Enti Pubblici di Ricerca in Italia, Pavia: Edizioni ETS.

Simmons, T.J. (2017). «Perspective: Can The Entrepreneurial University Solve The Postdoc Problem?», Postdoc Journal, vol. 5 n. 3, pp. 40-46.

Trow, M. (1973). Problems in the Transition from Elite to Mass Higher Education, Berkeley: Carnegie Commission on Higher Education.

Trow, M. (1999). «From Mass Higher Education to Universal Access: The American Advantage», Minerva, vol. 37, pp. 303-328.

Trow, M. (2006). «Reflections on the Transition from Elite to Mass to Universal Access: Forms and Phases of Higher Education in Modern Societies since WWII», in J.J. Forest, P.G. Altbach (eds.), International Handbook of Higher Education, Dordrecht: Springer, pp. 243-280. 